Hearing from parents and families in South Africa about how to protect the youngest children during the COVID-19 pandemic

1. We want to make sure that you have read and understand the information that we have given you about the survey:

$\square$ Yes, I understand

$\square$ No, I don't understand

2. You are 18 years or older:

$\square$ Yes

$\square$ No

3. You are the parent or caregiver of a child younger than 5 years:

$\square$ Yes

$\square$ No

4. You consent to participate in this survey:

$\square$ Yes

$\square$ No

5. The area you live in is best described as:

City or town

Suburb

$\square$ Township

$\square$ Informal settlement in an urban area

Informal settlement in a rural area

Village or farm

Tribal area

$\neg$ Other

6. You are a:

Mother

$\square$ Father

7. To how many children:

8. Please add the age and sex of each child:
0-6 months' old
boy $\square$ girl
6 months - 1-year-old
boy $\square$ girl
1 year - 3 years' old
boy $\square$ girl
3 years - 5 years' old
boy $\square$ girl 
9. You have missed a clinic appointment, like an immunization visit, because of the coronavirus pandemic:

$\square$ Yes

$\square$ No

10. This happened because: (PLEASE CHOOSE EACH ONE THAT APPLIES TO YOU) $\square \mathrm{I}$ am worried about my child being infected I am not allowed to leave the house because of the lockdown Someone in the household prevented me from going $\square$ I haven't got enough money to pay for transport $\square$ I haven't got enough money to pay for the health service $\checkmark$ The clinic or health service is not operating $\square$ I couldn't get off work

Other

11. Your childcare, childminding arrangements or your child's crèche/nursery/preschool attendance been disrupted:

$\square$ Yes

$\square$ No

12. This happened because: (PLEASE CHOOSE EACH ONE THAT APPLIES TO YOU)

$\square$ I am worried about my child being infected

$\square$ l am not allowed to leave the house because of the lockdown

$\checkmark$ The childminder, crèche or preschool is not open

$\square$ I haven't got enough money to pay for the transport

I haven't got enough money to pay the childminder, crèche or preschool

Other

13. Breastfeeding my baby is difficult during this time:

$\square$ Yes

$\square$ No

14. This happens because (PLEASE CHOOSE EACH ONE THAT APPLIES TO YOU)

$\square$ I am worried about infecting my baby

$\neg$ People in my family have advised me not to give breastmilk to the baby

My doctor or health provider advised me not to give breastmilk to the baby

$\neg$ My milk is not enough

$\neg$ am stressed and my milk is not enough

I don't have soap and clean water to clean my breasts

Other

15.I am struggling to properly feed my young child:

$\square$ Yes

$\square$ No 
16. This happens because: (PLEASE CHOOSE EACH ONE THAT APPLIES TO YOU) $\square$ There's not enough good food in the house because we don't have enough money $\square$ There's not enough food in the house because I am scared to go out

$\square$ There's no transport to get food

$\square$ I don't have enough money for transport to get food

$\checkmark$ No food is being sold or is available near where I live

$\square$ My child is unwell, restless or irritable and doesn't want to eat

Other

17. It is difficult to be affectionate to my child during this time:

$\square$ Yes

$\square$ No

18. This happens because: (PLEASE CHOOSE EACH ONE THAT APPLIES TO YOU)

$\square$ I am stressed and irritable

$\square \mathrm{I}$ feel hopeless, I am depressed and withdrawn

$\square$ My child is crying a lot and is difficult to comfort

$\square$ There is a lot of tension in our house

$\square$ Other

19. Someone in the household has been angry and violent towards my child:

$\square$ Yes

$\square$ No

20. This happened because: (PLEASE CHOOSE EACH ONE THAT APPLIES TO YOU)

$\square$ They lost their temper and hit my child

$\square$ My child was getting close to danger (fire, water, poison, etc.)

$\square$ My child broke or took something they weren't supposed to touch

Other

21. The angry and violent person was: (PLEASE CHOOSE EACH ONE THAT APPLIES TO YOU)

$\square$ You

$\square$ Another adult

$\square$ Another child

22. Do you find your child more difficult to deal with?

$\square$ Yes

$\square$ No

23. I am dealing with my child's behavior by: (PLEASE CHOOSE EACH ONE THAT APPLIES TO YOU)

$\checkmark$ Punishing them because my child is being naughty

$\square$ Trying to comfort and calm my child

$\square$ Trying to get other people in the house to calm and distract my child

$\square \mathrm{I}$ don't know what to do

$\square$ Other 
24.I have received help from my neighbours, community or faith group:

$\square$ Yes

$\square$ No

$\square$ I don't need help

25. What kind of help: (PLEASE CHOOSE EACH ONE THAT APPLIES TO YOU)

$\neg$ Food

$\neg$ Medicine

$\neg$ Information

Masks, soap, sanitizer, gloves to protect us from coronavirus

$\checkmark$ Lent or given me money

$\checkmark$ Helped with work around the house or yard, like cleaning, fetching water and so on

$\neg$ Transport to the clinic or shops

$\square$ Looked after my child

Given me support for mental distress, e.g. sat with me, prayed for me

$\neg$ Other

26.I have received help from government:

$\square$ Yes

$\square$ No

$\square$ I don't need help

27. What kind of help: (PLEASE CHOOSE EACH ONE THAT APPLIES TO YOU)

Food parcels

$\checkmark$ Clothes, blankets

$\neg$ Information

$\checkmark$ Medicine

Masks, soap, sanitizer, gloves to gloves to protect us from coronavirus

$\checkmark$ Given me clean water

$\checkmark$ Money or vouchers

$\square$ Transport to the clinic or to the shop

$\checkmark$ Support for my mental distress, like counselling

$\square$ Other

28. I have received help from any non-government organizations:

$\checkmark$ Yes

$\neg$ No

$\neg$ don't need help

29. What kind of help: (TICK EACH ONE THAT APPLIES TO YOU)

Food parcels

$\checkmark$ Clothes, blankets

$\neg$ Information

$\checkmark$ Medicine

Masks, soap, sanitizer, gloves to protect us from coronavirus 
Given me clean water

Money or vouchers

$\square$ Transport to the clinic or to the shop

Support for my mental distress, like counselling

Other

30. What help do you most need to look after yourself and your child: (PLEASE CHOOSE EACH ONE THAT APPLIES TO YOU)

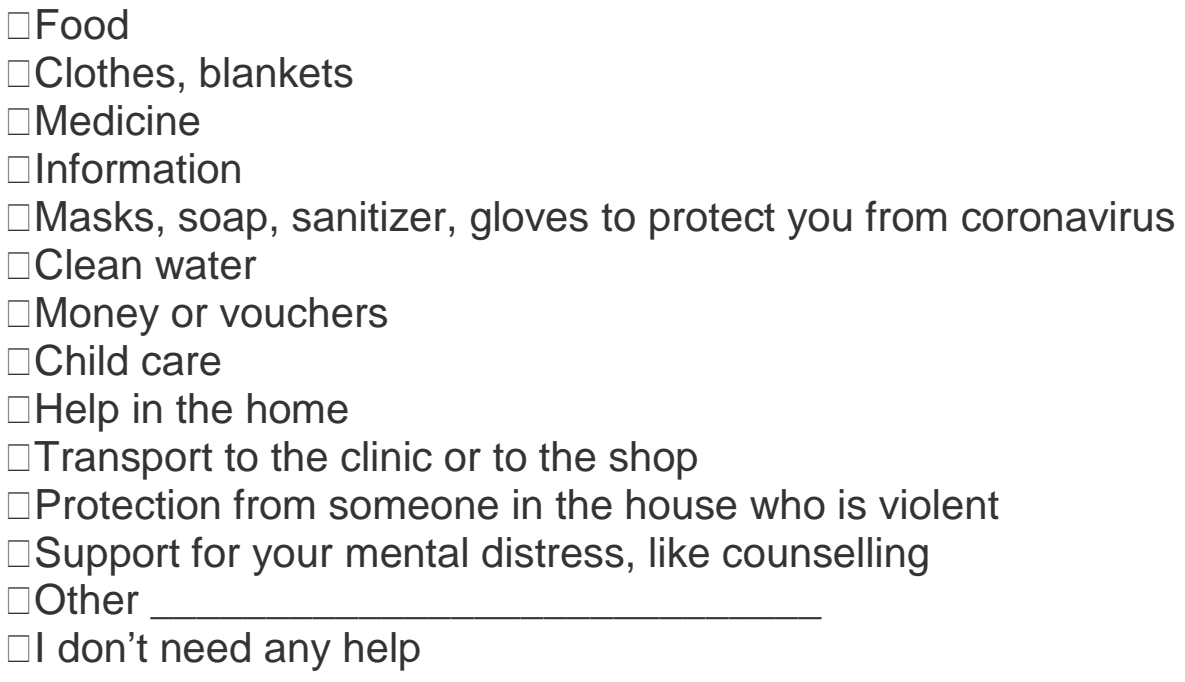




\section{DISQUALIFICATION PAGE}

UNDER 18S AND NON-PARENTS DIRECTED TO THIS MESSAGE:

This survey is only for individuals 18 years and older who care for children under the age of 5 years.

Thank you for your interest. For more on our work, visit us at www.wits.ac.za/coehuman.

\section{DENIED CONSENT PAGE}

\section{THOSE WHO DON'T CONSENT DIRECTED TO THIS MESSAGE:}

You have been directed to this page because you chose not to participate in the survey.

If this was a mistake, you can follow the link again to complete the survey.

If not, thank you for your time. For more on our work, visit us at www.wits.ac.za/coehuman. 